\title{
MERTZ IN HOBART: IMPRESSIONS OF ONE OF MAWSON'S MEN WHILE PREPARING FOR ANTARCTIC ADVENTURE
}

\author{
by Anna Lucas \\ (with four plates)
}

\begin{abstract}
Lucas, A. 2012 (14:xii): Mertz in Hobart: impressions of one of Mawson's men while preparing for Antarctic adventure. Papers and Proceedings of the Royal Society of Tasmania 146: 37-44. https://doi.org/10.26749/rstpp.146.37 ISSN 0080-4703. School of English, Journalism and European Languages, University of Tasmania, Private Bag 82, Hobart, Tasmania 7005, Australia. Email: Anna.Lucas@utas.edu.au

The story of the Australasian Antarctic Expedition (AAE) 1911-1914 has often been told in many publications which also refer to the drama of the Far-Eastern Sledging Journey from which Mawson trudged back to base, arriving in a desperate condition after both his companions, Xavier Mertz and Belgrave Ninnis, had died. Sir Douglas Mawson's career is well documented but we know less about his team of men and their work. What do we know of Mertz? The literature repeatedly notes that he was Swiss, held a doctorate in law, was a ski champion, looked after the expedition's dogs and died, mysteriously, on that Far-Eastern Sledging Journey. Details of his death have stimulated much discussion. But what of his life? Born in Basel in1882, he was six months younger than Mawson. With Ninnis he sailed from London on the AAE's S.Y. Aurora and spent November 1911 in Hobart as the team made final preparations for their Antarctic expedition. This paper focuses on that month of new experiences for the Swiss member of Mawson's team, his impressions of Hobart, the city's response to Antarctic explorers, what has changed and what remains as it was then.
\end{abstract}

Key Words: Antarctic, dogs, expedition, Hobart, Mawson, Mertz, quarantine, Switzerland, wharf.

\section{INTRODUCTION}

When Mawson returned from the Australasian Antarctic Expedition (AAE) in 1914 he, with the help of the expedition's doctor, Archibald McLean, collated and edited individual accounts of AAE members to produce an informative, illustrated narrative of their experiences, published as The Home of the Blizzard (Mawson 1915). This preceded publication of the expedition's scientific reports and with fundraising intent, appealed to the general reader. It offered a comprehensive background to the involvement of all AAE members, including Xavier Mertz (pl. 1). Mawson spent long months planning and organising this expedition, agonising over funding yet driven by the scientific potential of unknown territory. As a geologist, based at the University of Adelaide, South Australia, and interested in glacial influence on rock formations, he had taken an opportunity to travel south with Ernest Shackleton's British Antarctic Expedition (BAE) 1907-1909 (Shackleton 1909), to make further observations. His experiences on that trip were to seed his lifelong fascination with Antarctica. Within two years he was planning his own venture, drawing on the expertise of scientists and other professionals in the polar network to which he had been inducted.

After returning from the BAE, Shackleton undertook a series of lecture tours in 1910 in America and Europe, including Switzerland. Xavier Mertz, a keen mountaineer and ski enthusiast, possibly attended the lecture that Shackleton delivered in Basel. Lantern slides and cinematography accompanied the talk (National Zeitung 1910) and whether inspired by this presentation or enthused by another prompt, Mertz applied in early 1911 to the London office made available by Shackleton for Mawson when the latter was making arrangements for the AAE. The Mertz application to Mawson listed his academic and sporting achievements; he had graduated with a doctorate in law with a thesis on

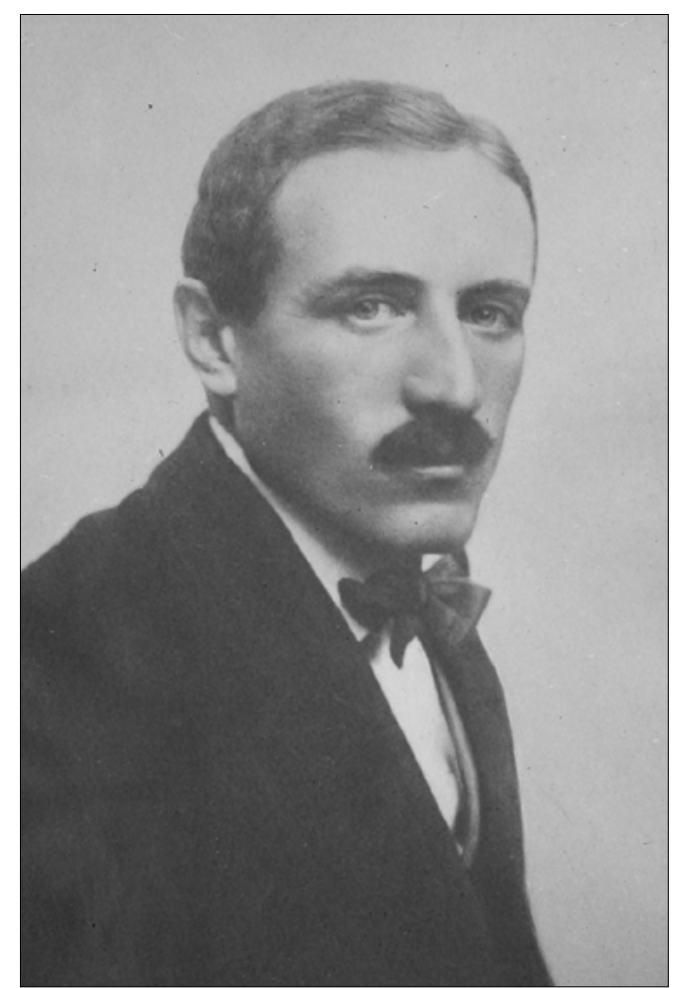

PLATE 1

Dr Xavier Mertz (1882-1913) prior to leaving on the Australasian Antarctic Expedition in 1911. Photographer unknown. Mawson (1911a) acknowledged receipt of a photograph of Mertz when in London. It is possibly a selfportrait. Image supplied by and reproduced with permission of the South Australian Museum (Mawson Collection). 
patents from the University of Bern in 1907, had won a Swiss national ski championship in 1908 and had climbed several mountains, including Mt Blanc $(-4800 \mathrm{~m})$ in the Alps (Mertz 1911a). In his father's factory he had learnt the principles of trades such as metalwork and carpentry. He had attended a school for engineers and had served his obligatory time in the Swiss Army. With his older brother Viktor, an engineer, he had been groomed to take over the running of the factory. However, a family dispute, centred around the rather autocratic father, resulted in both sons leaving: Viktor for New York and Xavier for Antarctica. This expedition may have been, for the 28-year-old Xavier, one last chance for adventure before surrendering to the responsibilities of the family business.

Xavier Mertz did not return. Hypotheses examining possible causes of his death in Antarctica have been the subject of much debate in the literature and will be discussed only briefly as here the focus is on the life of Mertz and particularly the month he spent in Hobart prior to the AAE's departure from that city. Impressions he recorded in his diary and in his three letters to friends suggest that he was optimistically and enthusiastically engaged with his surroundings. His observations are made with a high level of interest and an understated humour.

\section{PREPARATIONS FOR ANTARCTICA}

Most of the men selected for the AAE were young science graduates from Australian and New Zealand universities. Others, like Frank Hurley the official photographer, were specialists in an associated field. Mertz was not a scientist but Mawson, seeing potential in his proactive approach and his all-rounder attributes, accepted him. His ice experience would be invaluable and his practical skills would complement those of the other men. Mertz was asked to source alpine gear, including ropes, crampons and ice axes (Mawson 1911a) from Swiss companies and was sent to learn techniques of using water sampling and sounding equipment at the leading oceanographic institute in Europe, in Monaco (Mawson 1911b). Oceanography was, in 1911, a relatively new science and an important component of Mawson's planned scientific program. The Prince of Monaco, a keen oceanographer who supported the ventures of several of his contemporaries (Carpine 2002), lent the AAE most items of essential equipment requested (Mawson 1911c), including sounding and dredging equipment, trawling nets, and water sampling bottles.

After arriving back in London in July 1911, Mertz joined the AAE's ship, recently purchased with funds that flowed from a newspaper appeal endorsed by Shackleton (Daily Mail, London 1911). The ship, S.Y. Aurora, was placed under the command of John King Davis who had been first officer on Shackleton's Nimrod. Mawson had observed Davis in action during the BAE and wanted him to captain the AAE's ship. Here Mertz met his travelling companion, the 24-year-old Lieutenant Belgrave Ninnis. This young career soldier had taken special leave from his regiment, then based in Mauritius, to join a polar expedition, as his surgeon father had done. Ninnis and another AAE member, aircraft mechanic Frank Bickerton, had been directed to undertake a course of instruction in surveying prior to the ship's departure from London (Haddelsey 2005). As the only non-sailors on board S.Y. Aurora, Mertz and Ninnis had, as their main duty on the outward voyage, the care of
48 Greenland sledge dogs. Neither had any expertise in this work, but for the lawyer Mertz and the soldier Ninnis, "dog handler" became their job description by default.

The ship sailed first to Cardiff for coal, to Cape Town for supplies and for repairs, then to Hobart. Dogs and men adapted, not always well, to conditions on board, from the extremes of tropical weather to near freezing temperatures in higher latitudes near the Kerguelen Islands to where the ship had sailed to take advantage of the westerly winds to Tasmania. Heavy seas washed some dogs overboard, others died from distemper. Pups were born but few survived. Mertz built shelters for the animals but powerful winds and the action of waves crashing over the deck dismantled these temporary constructions (Mertz 1911-1913a, b). An enthusiastic photographer, who in later months enjoyed excursions with the AAE's Frank Hurley, Mertz was able to indulge his hobby on board. He set up a darkroom for developing and printing his images which documented aspects of shipboard life in calmer periods. Just after leaving Cape Town, with Ninnis and three other men he took a lifeboat and rowed for some distance from the ship to photograph it at sea. The captain, often scathingly critical and always a little ambivalent about his two passengers, was pleased with their efforts (Davis 1911a). As novice seamen, they did not always meet his expectations, but on 30 September 1911 he wrote: "Mertz tried his hand at steering and I found him a first rate helmsman. He was at ease as soon as he understood what was to be done". They had few calm days; storms and high seas made the 38-day passage (27 September-4 November) from Cape Town to Hobart difficult for men and dogs (Mertz 1911c).

\section{FIRST IMPRESSIONS OF HOBART}

As they neared Tasmania, all hands were given tasks to improve the appearance of the ship before it arrived in port. Mertz and Ninnis painted masts and other woodwork (Davis 1911b). They worked as replacements for crew who fell ill towards the end of the voyage, oiling the engine and stoking the furnace (Mertz 1911-1913c). During the trip, both men kept a diary, a habit they continued for the duration of the expedition, recording impressions of their surroundings, their companions, the work and the weather. Mertz wrote in German and the excerpts quoted in this paper are translated from his letters to friends or from a typed transcript of his diary entries. The whereabouts of his original handwritten diary, despite various attempts by researchers to trace it, is unknown.

After the challenging voyage from Cape Town, everyone onboard S.Y. Aurora was impatient for landfall, for civilisation and the comforts of civilisation. As Captain Davis noted in his diary (1911c), the first anticipated point of contact would be potentially rewarding.

A 10/- sweep as to the time of the pilot boarding the ship has been got up in the ward room and someone stands to win £3/10/-. We are all in it and Ninnis is looking after the matter.

With anticipation, Mertz recorded their approach to Tasmania:

At noon on 3 November we saw the first land, far faraway, a faint shimmer. Only after looking out for a long time was I able to recognise the land as land. Closer and closer came the Tasmanian coast, with quite beautiful mountains. Soon we caught sight of a 
ship, the first since Cape Town (Mertz 1911-1913d, 3 November 1911).

Later, in a letter to friends he wrote:

Eucalyptus trees form open woodlands. Our laburnum trees and fir trees are nowhere to be found. The typical Tasmanian bush (understorey) with enormous tree ferns stretches to the sea ... interesting rock formations. (Mertz 1911 , December 1911, p. 2)

The hilly terrain was a welcome sight for Mertz who loved the arduous ascents of alpine regions in his homeland, who had taken time to climb two mountains when in Cape Town and who had often climbed Aurora's main mast to the crow's nest where he sang, yodelled or just sat and contemplated the changing mood of the ocean.

As the ship made its way up the River Derwent towards Hobart on the afternoon of 4 November 1911, the pilot came on board. This was an important moment and Mertz noted that Harry Corner, the second engineer, won the sweep. Mawson, who had arrived in Hobart from Adelaide two days previously (The Examiner 1911), also boarded the ship in the stream, bringing with him newspapers and mail for Mertz and Ninnis who "had the doubtful pleasure" of accompanying 40 dogs to the Quarantine Station at Crayfish Point near Taroona instead of proceeding immediately to the Hobart docks (Mertz 1911d, December 1911 p. 3). The lifeboat was lowered, the dogs offloaded, and the men rowed to shore. On the second run the boat, overladen with dogs, crates of dog biscuits, men, hand luggage and blankets, sprang a leak. The dogs were put out to swim to shore, the men bailed furiously, rowed in as far as they could and dragged the boat the last few metres. Local people arrived to help secure the dogs and, with potential chaos averted, Mertz and Ninnis (who had received no communications for over a month - since Cape Town) were eager to sit and read the now sodden newspapers and personal letters. They read of an uprising in China, tensions between Germany, England and France, war between Turkey and Italy and a workers' strike in Sydney. That night they slept in the open with the dogs (Mertz 1911d). Mertz does not record what rations they had nor if the blankets dried, but though conditions were uncomfortable, they (and the dogs) had been conditioned to privation en route, especially on the Cape Town to Hobart leg of the voyage.
Next day the Chief Quarantine Officer, Mr T. Tabart, examined the dogs and briefed the men on regulations and expectations. The dogs were physically unfit after being for so long in such confined conditions and were in need of a more varied diet. Distemper, the contagious canine disease which had plagued them during the voyage, still threatened. When initial instructions had been given, Tabart drove Mertz and Ninnis into Hobart in his two-horse carriage. "First impressions could not be better" (Mertz 1911-1913e, 5 November 1911). "These waterways remind me of our Swiss lakes ... They are ideal for sailing” (Mertz 1911d, December 1911 p.5). The backdrop of Mount Wellington, the low-density housing and colourful gardens of late spring all impressed him. Hobart then was a city of 27719 people (Census 1911), with substantial buildings, streets lit with electric lamps (Petrow 2002), trams (pl. 2), and an extensive port area to cater for shipping including exports of wool, minerals, timber, grains and fruit (Walch's Almanac 1912).

In Hobart they met again with Mawson and some of the early arrivals. The AAE had established an office, with Conrad Eitel as administrator, in the building then occupied by the Tasmanian Tourist Association, opposite the General Post Office on the corner of Macquarie and Elizabeth Streets. Later that day Mertz enjoyed the luxury of a hot soapy bath - the first since Cape Town - and worthy of a mention in his diary (Mertz 1911-1913e).

\section{WORK AND PLAY IN HOBART}

After spending a day in the city, Mertz and Ninnis were obliged to return to the Quarantine Station. Two dogs had died of distemper. Others had been isolated but, as an additional precaution, Tabart subjected those dogs to a disinfecting dip (The Mercury 1911a). He also prescribed a more nourishing diet: "Some boiled sheep paunches, liver greaves mixed with oatmeal once a day, fish once a day, boiled cabbages and meat once a week" (Tabart 1911, p. 1). The introduction of a varied diet was undoubtedly beneficial and appreciated by the dogs. However, it is now illegal in Tasmania to feed offal to dogs (DPIPWE 2011).

Arrangements had been made for the two dog handlers to stay at the Fitzpatricks' place nearby. It was in a shed away

\section{PLATE 2}

Elizabeth Street, Hobart c.1911. The clock tower of the General Post Office, opposite which the $A A E$ maintained an office, can be seen mid-image. Photographer uncertain. Part of the collection of photographs compiled by Australian photographer E. W. Searle while working for $J$. W. Beattie in Hobart during 1911-1915. Image supplied by and reproduced with permission of the National Library of Australia.

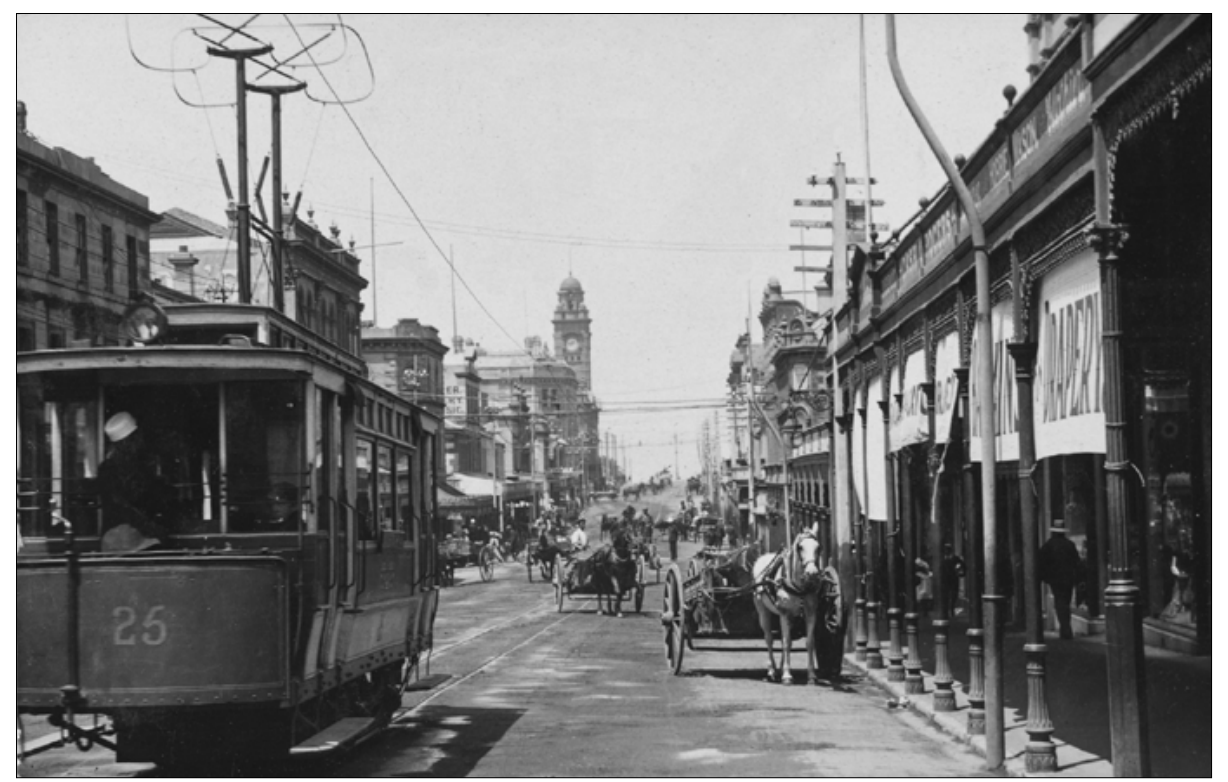


from the main house - "a cow barn", according to Mertz (1911-1913f, 6-10 November 1911). Other expeditioners had been billeted closer to Hobart in homes or boarding houses so, with a touch of his sometimes sardonic humour or perhaps to mask his disappointment, Ninnis named this basic shelter The Ritz. Hannah Mornemont noted, when retracing the journey of her great-great-uncle Belgrave 89 years later, that spectacular views across the river could have compensated for the shed's lack of comfort (Mornement 2004). Mertz and Ninnis adapted to their surroundings and settled into their new routine, caring for the dogs, lazing on the beach or rigging a makeshift sail - and the Swiss flag - on the repaired lifeboat (now named Davis after S.Y. Aurora's captain) and making not always successful attempts to launch it. Their presence was not unnoticed. "The daughters of the community bring some diversion.... We have already been invited to the yacht club and to tennis.” wrote Mertz (1911-1913g, 6-10 November 1911). Another day, as they brought the little boat in, an old man approached them, curious about the significance of their flag (pl. 3). He believed he knew the flags of all nations, but had never seen one with a white cross on a red background. When told it was the flag of Switzerland, he amused Mertz by demanding to know why the Swiss fleet or its merchant ships had not previously visited Hobart (Mertz 1911-1913 h). Switzerland at that time did not have any ships on the high seas, only on the lakes.

A bicycle was available for their use and they took it in turns to ride into the city. Trams ran from the city to Long Beach in Lower Sandy Bay then, and the men could have ridden to that point from Taroona and completed the journey by tram, but it is more likely that they continued the ride to the city. Mertz read the shipping column first in the daily newspapers to gain greater cognisance of the harbour traffic (Mertz 1911-1913i). Ships brought more of their supplies from Britain, Europe, the Australian mainland or from New Zealand. Fellow expeditioners arrived by ship or by train. There were plenty of opportunities during his month in Hobart for socialising and sightseeing. He mentions meeting a "Miss Hoob" (Shoobridge?), "Dr. Sprent" and "Sorrell" (Mertz 1911-1913j, 10 November-2 December 1911). As well as yachting and tennis, he and Ninnis were invited to golf, dances, picnics and family dinners. Also on his list were Mount Wellington and inland Tasmania. Some men took a dray part way up the mountain, from where they trekked to the summit (Madigan 2000). Mertz was invited to an evening picnic and, recalling the forest huts near the inland lakes, wrote in his diary: "I shall never forget that moonlit night” (Mertz 1911-1913k, 7-9 December 1911). Later in a letter to friends he describes kangaroos and tigers on the banks of a lake, venomous snakes slithering in the grass (Mertz 1911d). He may have seen a Tasmanian Tiger (thylacine) there; the species was not yet extinct and it is likely that the unusual wildlife of the region would have been discussed. Alternatively, this could have been a simplification of his experiences, because he later visited a Hobart zoo where he did see Tasmanian Tigers (Blake 1911a).

In the last two weeks before the AAE's departure, the most important work was on Queen's Pier where S.Y. Aurora was berthed. Yorkshireman Frank Wild, an Antarctic veteran, had already arrived to oversee the wharf operations in Hobart. Eric Webb, the magnetician, had arrived from New Zealand. Biologist and artist, C.T. Harrisson, lived in Hobart and was the only Tasmanian member of the expedition. Several men arrived from Sydney on S.S. Paloona (The Argus 1911a);

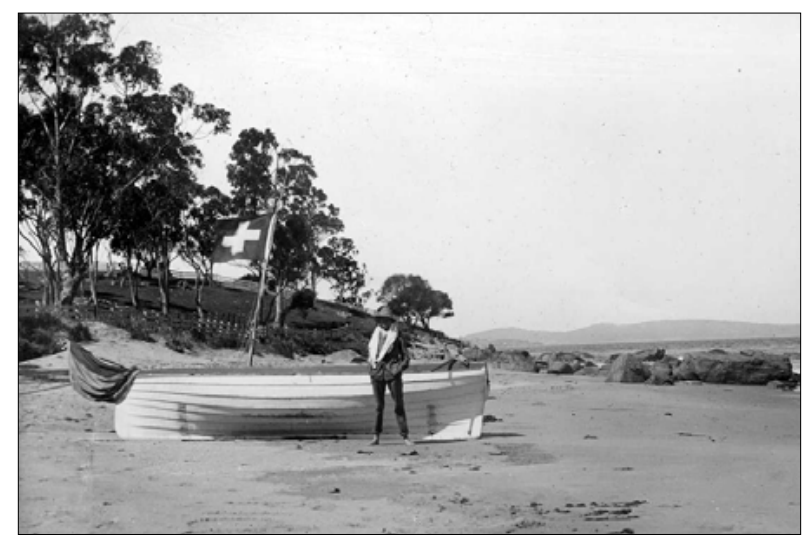

PLATE 3

The Swiss flag on the rowboat near the Quarantine Station south of Hobart where Mertz and Ninnis (pictured) spent some of their time caring for the expedition's dogs. Photographer: Xavier Mertz. Image supplied by and reproduced with permission of the South Australian Museum (Mawson Collection).

others came from Adelaide and Melbourne, crossing Bass Strait to Launceston on S.S. Loongana (The Argus 1911b), then completing the trip to Hobart by train. Ernest Joyce, who had accompanied Scott and Shackleton as dog trainer, came on the Corinthic from England to join the AAE (The Mercury 1911b). Joyce was held in high regard by his former co-workers, but after an imprudent drinking bout and other annoyances he was dismissed, perhaps unfairly, by Mawson (Riffenburgh 2011). Joyce visited the Quarantine Station where he spoke to Mertz about training dogs in Antarctica (Mertz 1911-1913l) and while details of this exchange are not recorded, Mertz, whose only experience with Greenland sledge dogs was that gained on the three-month voyage from London, would have appreciated his advice.

On the wharf, equipment and supplies had to be repacked, coded for the Macquarie Island base or the three (later two) Antarctic bases, and reloaded onto S.Y. Aurora or prepared for the chartered support ship S.S. Toroa that would later take the second contingent of men and additional supplies to Macquarie Island (administered by Tasmania since 1900) where a wireless relay station and a meteorological station were to be established. Horses brought carts laden with crates for the AAE to the wharf. "There are many horses in this country," observed Mertz, recalling his first road trip into Hobart and other sightings. "Butcher assistants gallop through the main streets of the town with the meat basket on their arm. Errand boys deliver their packets mounted on horseback" (1911d, December 1911, p. 5).

$\mathrm{He}$ met and worked with other expeditioners on the wharf. Though he was still not fluent in English, any disadvantage was overcome by his good-natured acceptance of the inevitable teasing and his willingness to contribute to the overall effort. "My mistakes in English are so bad that they make jokes without trying" he had written previously to his friends (Mertz 1911b, September 1911, p.11). One of his co-workers was Cecil Madigan, a University of Adelaide geology graduate, who had deferred his Rhodes Scholarship appointment at Oxford University in England to participate in the expedition, who had an understanding of German, and who later became a close friend.

The working arrangement on the wharf was that the expeditioners would repack in the sheds and that union members would load the ship. When one of the AAE men 
inadvertently carried a case onboard, an argument broke out and the unionists threatened to strike. Fortunately for the expedition's already tight schedule, the dispute was resolved before the threat was carried out (The Mercury, 1911c). Some incidents on the wharf benefited those who were in the right place at the time, for example when a large case of walnuts broke open one day during wharf operations and a group of delighted youngsters nearby were able to scoop up the scattered windfall (The Mercury 1911d). Other food that had spoiled on the voyage from London had to be discarded (Madigan 2000).

The work continued: prefabricated huts for the bases arrived from Sydney; the motor boat and numerous crates were loaded. The aeroplane arrived; it was now wingless after a crash ended its test flight in Adelaide injuring the pilot and less severely his passenger, Frank Wild. Destined to have limited use as a motor sledge in Antarctica, it too was stowed on the crowded deck (Lucas et al. 2011). During those busy days, carpenters made necessary alterations to the ship, and people visited. Newspaper reporters interviewed Mawson, Davis, Wild, Mertz and others. The expeditioners' clothing was distributed and Madigan and Webb, two of the most serious of the scientists, attracted public attention by walking through the streets dressed in their Antarctic outfits to the Town Hall, where they entertained the audience with a clowning routine on stage, prior to Mawson giving his lecture (Madigan 2000). When S.Y. Aurora had to be repositioned with its bow facing seaward to facilitate departure, this feat was accomplished "with a great deal of shouting" by men hauling on opposite sets of ropes attached to bow and stern while a small steamer simultaneously gave encouraging nudges (The Mercury 1911e).

One day, while working on the wharf, Mertz was surprised to hear a man greet him in Swiss German. After speaking mostly English for several months - "only our dogs understand Schweitzerdeutsch" (Mertz 1911b, September 1911, p. 1) - he felt that the sound of his own response was strange. His compatriot was not from Basel, but from another Swiss canton, St Gallen, had spent almost four decades in Australia, and was Professor of Modern Languages (French and German) at the University of Tasmania (Mertz 1911d). Professor Hermann Ritz had also researched the languages of Tasmania's Indigenous people, and as a member of The Royal Society of Tasmania, had published papers on the subject (Ritz 1909, 1913). Recordings of Aboriginal singer Fanny Cochrane were made for his language studies, some at The Royal Society's rooms in 1899 (Jacques 2004). After meeting Mertz at the wharf, Ritz immediately invited him to lunch and later to his home. He gave Mertz a condensed history of Tasmania's colonisation, settlement, agriculture and indigenous people. Of all the people he met in Hobart, Mertz really enjoyed and later keenly missed the company of Ritz and his wife. It was an important meeting and propitious; after Mertz's death in Antarctica, Ritz would act as intermediary for the distraught Mertz family and the AAE administration. While Mertz was in Hobart this friendship offered a welcome opportunity to revert to a familiar language and cultural environment, but the dichotomous effect of the association was both an immediate salve to an occasional bout of homesickness and afterwards a catalyst to reactivate those same pangs.

On the streets of Hobart the AAE men were "to be found everywhere, especially in Elizabeth Street with strawberries and cream" (Mertz 1911-1913m). Some of the favourite haunts of the AAE men were city fruit shops. "In nearly every fruiterer's shop here there is a kind of little back parlour where you can sit and gorge this delicious pottage" (Ninnis 1911, cited by Riffenburgh 2011, p. 97). Here the seasonal abundance of strawberries was exploited without restraint. The men would have been aware that fresh produce would soon be replaced by tinned and dried food and by expedition rations.

With constant media coverage, as a collective the expeditioners had gained almost celebrity status and as the day of departure drew nearer, more official functions were attended. Mawson gave two lectures in the Town Hall under the auspices of The Royal Society of Tasmania (The Mercury 1911f). Bishop Mercer conducted a special service for the expedition at St. David's Cathedral, commenting on the courage and enterprise of the AAE (The Mercury 1911g). On the eve of departure, the Premier of Tasmania, Sir Elliott Lewis, and Lady Lewis hosted a celebratory farewell for the expedition at the museum, where all invitees were treated to more strawberries and cream (Madigan 2000). Mertz (1911d) noted reflectively that he had never eaten as many strawberries as he had during his month-long stay, but expedition members missed the Annual Strawberry Feast in Hobart that summer (The Mercury 1912).

\section{DEPARTURE AND BRIEF RETURN}

On Saturday afternoon, 2 December 1911, after lunching at Hadley's Orient Hotel in Murray Street (The Mercury 1911h), Mawson and some of the team boarded the heavily laden S.Y. Aurora, which left with great ceremony from Queen's Pier at 4:00 pm (The Mercury 1911i). As Frank Hurley, the expedition's official photographer documented the departure with cinematography, Mertz climbed into the rigging to record the event with his camera:

Observing an old seafaring tradition, the sailors threw their last money away. Only empty pockets bring luck at sea. People stood in great masses on the wharves... The Governor of Tasmania appeared, a band played, the ropes were let go. With innumerable cheers and a gun salute, the Aurora departed, surrounded by sailing boats, rowing boats, motorboats and an accompanying steamer. (pl. 4) (Mertz 1911-1913n, 10 November-2 December, 1911)

The Governor, His Excellency Sir Harry Barron, summoned Harrisson just before departure, congratulated him on his appointment to the AAE and urged him, as the lone Tasmanian, to do his best for the State (Rossiter 2011). At the Quarantine Station Ninnis, assisted by Joyce, was waiting with the dogs to board the ship. The first officer, who had not seen them for a month, remarked on the difference in the dogs' appearance "all fat with beautiful coats" (Gray 1914, p. 2). Here, most of the escorting flotilla turned back to Hobart as S.Y. Aurora, with one half of Mawson's team on board, set its course for the open sea and Macquarie Island. One hundred years later, as part of the Antarctic Centennial Year 2011-2012, a re-enactment of this event featured the Australian Antarctic Division's icebreaker Aurora Australis leading a flotilla of smaller craft in a sailpast on the River Derwent while the Governor of Tasmania, the Honourable Peter Underwood AC, took a 19-gun salute (Killick 2011).

Before S.Y. Aurora departed from the Quarantine Station, Mertz transferred to the pilot's boat which took him back to Hobart. That evening, he was seated in the newly built 


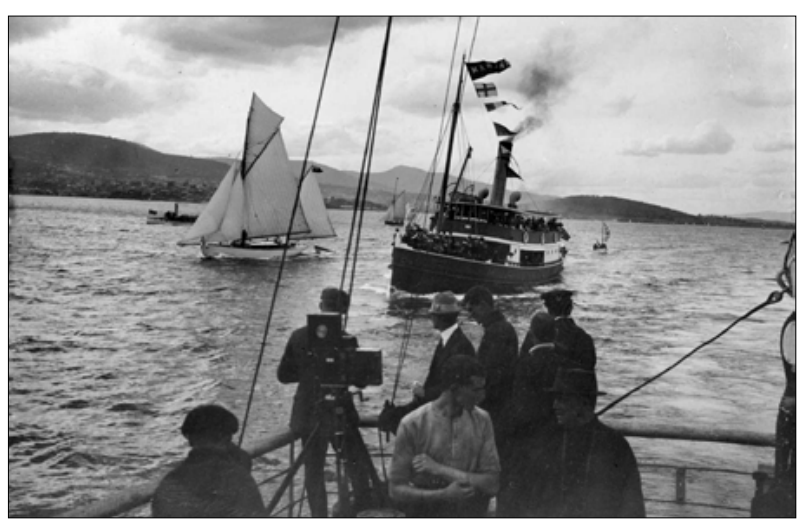

PLATE 4

A flotilla of smaller craft accompanied S.Y. Aurora on the River Derwent as the AAE left Hobart on 2 December 1911 bound for Macquarie Island and Antarctica. Frank Hurley's cinematograph is set up on the tripod at the stern. Photographer: Xavier Mertz. Image supplied by and reproduced with permission of the South Australian Museum (Mawson Collection).

Grand Empire Theatre in Macquarie Street where the musical comedy Our Miss Gibbs was a sold-out success (Mertz 1911-1913o, The Mercury 1911j). The days between the departure of S.Y. Aurora and S.S. Toroa were relaxed and offered a chance for more social activities. On one visit to his compatriot Ritz, he listened to gramophone recordings of Swiss yodelling. Fellow expeditioners were to note Mertz's propensity to burst into a spontaneous rendition of a yodelling favourite; this would both startle them and leave them bemused. Madigan later wrote of midnight on board S.Y. Aurora as the New Year of 1912 was welcomed "The relieving and relieved watches made a lot of noise, Mertz's yodel being pre-eminent" (Madigan 1912).

Mertz visited Beaumaris Zoo with Leslie Blake, the AAE geologist and cartographer who was to be stationed on Macquarie Island. They were accompanied by Miss Nita Pipe. At this zoo, privately owned by Mrs Mary Roberts in Sandy Bay Road, Battery Point, they saw five Tasmanian Tigers, (Thylacinus cynocephalus (Harris, 1808)) (Blake 1911b), possibly the "tigers" that Mertz referred to in his letter to friends (Mertz 1911d). As well as these marsupial tigers, this zoo, known for its extensive aviaries, kept Tasmanian Devils (Sarcophilus harrisii (Boitard, 1841)), Bennetts Wallabies (Macropus rufogriseus (Desmarest,1817)), Common Wombats (Vombatus ursinus tasmaniensis (Shaw, 1800)), and other animals (Guiler 1986). Mertz doesn't mention the zoo in his diary, nor in his letters, but he and Blake both signed the visitors' book (Roberts 1904-1921).

Five days after Mawson's departure, S.S. Toroa left Hobart to rendezvous with S.Y. Aurora at Macquarie Island, taking more live sheep, more stores and the second half of Mawson's team including a somewhat reluctant Mertz, wishing he could spend a few more days in Hobart (Mertz 1911-1913). Retrospectively, the poignancy of his last letter to his friends in Switzerland becomes apparent. Mertz wrote that he would not be able to write for more than a year and offered them a double Prosit! for two New Year celebrations (Mertz 1911d). Ever the patriot, he also wrote that he was taking the Swiss flag with him, intending to raise it at several places on the Antarctic continent (which he did). Also in his luggage was a Basler banner to use as a sledge flag, and a range of edible Swiss specialties that he would share with the AAE team when they celebrated Swiss Confederation Day with him in the remote hut at Commonwealth Bay (Mertz 1911-1913q). Later that same year on 6 October 1912, they celebrated his 30th birthday - his last.

\section{SUBSEQUENT DEVELOPMENTS}

In The Home of the Blizzard, Mawson (1915) fully described the Far-Eastern Sledging Journey on which his two companions Belgrave Ninnis and Xavier Mertz died. It was an observational and mapping exercise that went terribly wrong. He tells how, when Ninnis broke through an insubstantial snowbridge to fall to his death in the underlying and unfathomably deep crevasse, the main sledge, supplies and the strongest sledge dogs went down with him. Mawson and Mertz were stranded 300 miles $(-482 \mathrm{~km})$ from base, without adequate clothing or rations (Jacka \& Jacka 2008). They started the return journey, Mertz died on the way and Mawson arrived at the main base at Commonwealth Bay alone (Mawson 1915). Speculation on the cause/s of the death of Mertz varied. McLean's initial diagnosis of colitis in 1913 was based on Mawson's description of symptoms (Jacka \& Jacka 2008).

Subsequent medical research led to conjecture that ingestion of toxic levels of Vitamin A after eating the livers of the slaughtered dogs (Cleland \& Southcott 1969, Southcott et al. 1971) may have been a significant causal factor in the rapid deterioration of his health. Other contributing causes could have been malnutrition, exposure and hypothermia. It has also been suggested that the psychological stress of losing Ninnis, whom he considered his best friend on the expedition, and the loss of the dogs including his favourite, Basilisk, to which he had become so attached, were additional considerations and that to dispatch the remaining dogs and to eat them would have induced more pronounced stress for Mertz, since Mawson's association with them had been considerably less in preceding months (Carrington-Smith 2005). When Tim Jarvis re-enacted that journey, his aim was to examine the feasibility of Mawson's almost incredible account of one man's survival against all odds - an account questioned by Mawson's detractors. Travelling in similar clothing with similar rations and shelter, Jarvis concluded that such a journey was possible and that Mawson's version of events could be validated (Jarvis 2008).

As soon as Mawson returned to the main base, minimal details of the deaths of Mertz and Ninnis were relayed via wireless to S.Y. Aurora (which had already left and which had a receiving but no transmitting function), to Macquarie Island and to authorities who notified the men's families. A summary of Mertz's early association with the AAE was published in a Hobart newspaper (The Mercury 1913). Those who had worked so closely with the two men during the previous year in Antarctica were shocked. That they "were really dead seemed beyond belief” (Laseron 1947, p. 200).

The Mertz family were desperate for details. At that time, February 1913, erratic wireless communication meant that any updates would be limited until Mawson returned to Australia. Professor Ritz communicated with the family explaining the logistical problems of the situation and sought information about any further developments from the AAE administration so that he could keep the family informed, even contacting the Prime Minister of Australia on their behalf (Ritz 1913). On his return from Antarctica in 1914, Mawson wrote to the parents of Mertz and later 
visited them in Switzerland to give a personal account of their son's death (Mawson 1964).

Mertz had gained the respect of his fellow expeditioners. Initial impressions were recorded of the "foreignness" of Mertz (Laseron 1947, p. 22, Madigan 2000). Though mainly monolingual themselves, the men couldn't resist recording examples of his imperfect English. Their perception of him as "other" to their own experience was reinforced by his misuse of words, ungrammatical expressions, urbane demeanour with polite mannerisms, his yodelling and even, for them, his unusual name (Laseron 1947). The Southern Ocean and Antarctic ice were levelling influences, presenting testing conditions for all. Mertz did not suffer from sea-sickness and was an expert on ice, but more than these attributes, it was his affability and his conscientious approach to hard work that won their total acceptance and their deep respect. Their dual destiny and close friendship inextricably links the names of Mertz and Ninnis. Their names often appear in the same sentence, almost as one word, in many AAE accounts. Two glaciers near their places of death bear their respective names. Those who wintered at the main base for the second year in 1913 expressed their respect for the two men by erecting a memorial cross, with a plaque which reads:

Erected to commemorate the supreme sacrifice made by Lieut. B.E.S. Ninnis, R.F. and Dr. X. Mertz in the cause of science A.A.E. 1913.

The cross is still standing at Cape Denison in Antarctica (Australian Antarctic Division 2012).

Most of the AAE personnel, e.g., Eric Webb, John Hunter, Cecil Madigan and Captain Davis, returned home to build successful careers. Frank Hurley, Frank Bickerton and Frank Wild continued a life of adventure. Other members of the expedition, Leslie Blake and Robert Bage, were killed during World War I, 1914-1918, and Dr Archibald McLean died shortly afterwards from the effects of that war (Laseron 1947, Medical Journal of Australia 1922). Charles T. Harrisson was drowned when the Commonwealth Fisheries vessel, F.I.S. Endeavour, on which he worked as a biologist, foundered off Macquarie Island in 1914 (Court of Marine Inquiry 1915). These men were remembered when, in a ceremony in Franklin Square, Hobart on Empire Day 1918, Mrs C. Harrisson laid a wreath "in memory of Dr. Mertz and other comrades of C.T. Harrisson” (The Mercury 1918).

The streetscapes of Hobart have changed since 1911, but many places visited by Mertz still stand. The General Post Office, the Tasmanian Museum and Art Gallery, the Town Hall, St David's Cathedral (now with a bell tower) and Hadley's Hotel are landmark buildings. The site of the Quarantine Station is now occupied by the Tasmanian Aquaculture and Fisheries Institute. The University of Tasmania relocated from the Domain to Sandy Bay and grew to incorporate other campuses (Davis 1990) but now has plans to return some activities to the Domain site. Shops and offices have replaced the building where the AAE had its office. Trams ceased to run along Macquarie and Elizabeth streets in the 1960s; a network of buses now services a wider area. The Grand Empire Theatre, built in 1910, was renamed the Prince of Wales Theatre but demolished in the 1980s (The Examiner 1910, The Mercury 1987) to be replaced by an office building. Beaumaris Zoo, after the death of owner Mrs Mary Roberts, was transferred to the Domain in 1923 and closed in 1937 (Guiler 1986). Queen's Pier, after a partial collapse, was demolished in the 1960 s
(Hudspeth \& Scripps 2000) and the AAE's ship, S.Y. Aurora, after leaving Sydney with a cargo of coal bound for Iquique, Chile, disappeared without trace in 1917 (Moyser 1919).

Mertz may have been shielded from World War I by Switzerland's neutrality, but his father's death in 1916 and his older brother's continuing residence in America, would have obliged him to return to family responsibilities in Basel, if he had survived his adventure in Antarctica.

\section{ACKNOWLEDGEMENTS}

This paper was presented in November 2011 at "Mawson 100 years on: how things have changed" a symposium organised by The Royal Society of Tasmania and held at the University of Tasmania as part of the Antarctic Centennial Year 2011-2012 celebrations (Antarctic Centennial Year 2011).

I gratefully acknowledge the expertise of very helpful staff at the Tasmanian Archives and Heritage Office, libraries at the University of Tasmania, the State Library of Tasmania, the State Library of Victoria, the Mitchell Library at the State Library NSW, the Mawson Collection at the South Australian Museum, the National Library of Australia, the Musée océanographique in Monaco, and the University of Basel in Switzerland. I would like to thank Associate Professor Franz Josef Deiters and Julia Merk who helped so much with the translation and interpretation of the Mertz documents. I would also like to thank those who reviewed this paper for their very helpful suggestions and Dr Elizabeth Leane whose insightful comments improved the final presentation.

\section{REFERENCES}

The Argus newspaper (Melbourne) 1911a: 24 November 1911, p.6; 1911b: 21 November 1911, p.6.

Australian Antarctic Division 2012: Australian Antarctic Data Centre, Antarctic Heritage Register. Online at: http://data. aad.gov.au/aadc/artefacts/display_artefact.cfm?artefact_ id=665 (accessed 22 May 2012).

Antarctic Centennial Year 2011: Online at: www.antarcticcentennial. tas.gov.au/home (accessed 12 December 2011)

Blake, L. 1911: Personal Diary (unpublished manuscript). State Library of Victoria MS 9551 MSB 471: 1911a: 5 December 1911; 1911b: 5 December 1911.

Carpine, C. 2002: La pratique de l'océanographie au temps du Prince Albert Ier Monaco. Musée océanographique, Monaco: $331 \mathrm{pp}$.

Carrington-Smith, D. 2005: Mawson and Mertz: a re-evaluation of their ill-fated mapping journey during the 1911-1914 Australasian Antarctic Expedition. Medical Journal of Australia 183: (11/12) 638-641.

Census 1911: In Walch's Tasmanian Almanac for 1912. J. Walch \& Sons, Hobart.

Cleland, J.B. \& Southcott, R.V. 1969: Hyper-vitaminosis A in the Antarctic in the Australasian Antarctic Expedition of 1911-1914: a possible explanation of the illnesses of Mertz and Mawson. Medical Journal of Australia 1: 1337.

Court of Marine Inquiry 1915: Report of the Court of Marine Inquiry held at Melbourne on 20, 23, 27 and 28 April and 3 May 1915. F.I.S. Fisheries Investigation Steamship "Endeavour". National Archives of Australia, Canberra. Series No. A5522.

Daily Mail newspaper (London) 1911: 8 May 1911, p.9.

Davis, J.K. 1911: Personal diary (unpublished manuscript). State Library of Victoria, John King Davis Collection MS 8311 
3232/5. 1911a: 3 October; 1911b: 30 October; 1911c: 26 October.

Davis, R. 1990: Open to Talent. The Centenary History of the University of Tasmania 1890-1990. The University of Tasmania, Sandy Bay, Tasmania: $256 \mathrm{pp}$

DPIPWE (Department of Primary Industries, Parks, Water and Environment) 2011. Online at: www.dpiw.tas.gov.au/ inter.nsf/webpages/cart-6sa36r?open\#HydatidDisease in Tasm (accessed 12 December 2011).

The Examiner newspaper (Launceston), 1910: 30 December, p.6; 1911: 3 November, p.7.

Gray, P. 1914: Antarctic Voyages 1911-1914. Unpublished typescript. Australian Antarctic Division, Kingston, Tasmania. [

Guiler, E.R. 1986: The Beaumaris Zoo in Hobart. Papers and Proceedings of the Tasmanian Historical Research Association 33: $12-171$.

Haddelsey, S. 2005: Born Adventurer: The Life of Frank Bickerton. Sutton Publishing Ltd., Stroud: 255 pp.

Hudspeth, A. \& Scripps, L. 2000: Capital Port: A History of the Marine Board of Hobart 1858-1997. Hobart Ports Corporation Pty. Ltd, Hobart: 461 pp.

Jacka, F. \& Jacka, E. (eds) 2008: Mawson's Antarctic Diaries. Allen \& Unwin, Crows Nest: 414 pp.

Jacques, J. 2004. Passing the Torch: Commemorating the Songs of Fanny Cochrane Smith. Proceedings of the 2004 IASPM Australia New Zealand Conference. Online at: http://search. informit.com.au/fullText; $\mathrm{dn}=448098046811483$; res=IEL HSS (accessed 22 May 2012).

Jarvis, T. 2008: Life and Death in Antarctica. The Miegunyah Press, Melbourne: $239 \mathrm{pp}$.

Killick, D. 2011: Tribute to Antarctic Hero. Online at: www. themercury.com.au/article/2011/12/03/281621_todaysnews.html (accessed 12 December 2011).

Laseron, C. 1947: South with Mawson: Reminiscences of the Australasian Antarctic Expedition, 1911-1914. The Australasian Publishing Co. Pty Ltd. in association with George C. Harrap \& Co., Sydney and London: 223 pp.

Lucas, A., Henderson, C., Leane, E. \& Kriwoken, L. 2011: A flight of the imagination: Mawson's Antarctic aeroplane. The Polar Journal 1 (1): 63-75.

Madigan, C. 1912. Personal diary (unpublished manuscript). Privately owned by Madigan family. 1 January 1912

Madigan, D. 2000. Vixere Fortes; a Family Archive. Kingston, Tasmania: Private publication: 392 pp.

Mawson, D. 1911a: Letter to X. Mertz, 30 May 1911. Mitchell Library, State Library New South Wales. ML MSS 171/13x.

Mawson, D. 1911b: Letter to Dr. Jules Richard, 17 May 1911. Archives du Musée océanographique de Monaco. Lettres du docteur Jules Richard, Mawson file.

Mawson, D. 1911c: Letter to Dr. Jules Richard, 12 June 1911. Archives du Musée océanographique de Monaco. Lettres du docteur Jules Richard, Mawson file.

Mawson, D. 1915: The Home of the Blizzard: Being the Story of the Australasian Antarctic Expedition, 1911-1914. Vol. 1 \& 2. William Heinemann, London.

Mawson, P. 1964: Mawson of the Antarctic: The life of Sir Douglas Mawson, F.R.S., O.B.E. Longmans, London: 240 pp.

Medical Journal of Australia 1922: Obituary: Archibald Lang McLean. Med. J. Aust. (3 June): 619-621.

The Mercury newspaper (Hobart), 1911a: 7 November, p.4; 1911b: 25 November, p.8; 1911c: 25 November, p.8; 1911d: 27 November, p.6; 1911e: 30 November, p.6; 1911f: 28 November, p.6; 1911g: 27 November, p.6; 1911h: 2 December, p.5; 1911 i: 4 December, p.5; 1911j: 4 December, p.3; 1912: 9 January, p.6; 1913: 27 February, p.5; 1918: 25 May, p.8; 1987: 10 September, p.20.
Mertz, X. Personal diary 1911-1913 (unpublished typescript). Mawson Collection, South Australian Museum, SP, a: 26-31 August 1911; b: 12-15 October 1911; c: 22 October-3 November 1911; d: 22 October-3 November 1911; e: 5 November 1911; f: 6-10 November 1911; g: 6-10 November 1911; h: 10 November-2 December 1911; i: 10 November-2 December 1911; j: 10 November-2 December 1911; k: 7-9 December 1911; 1: 10 November-2 December 1911; m: 10 November-2 December 1911; n: 10 November-2 December 1911; o: 3-7 December 1911; p: 3-7 December 1911; q: 1 August 1912.

Mertz, X. 1911a: Application to D. Mawson (undated). Mawson Collection, South Australian Museum. 13 AAE.

Mertz, X. 1911b: Letter to friends, September 1911. Mawson Collection, South Australian Museum. MI 16.

Mertz, X. 1911c: Letter to friends, October 1911. Mawson Collection, South Australian Museum. MI 16.

Mertz, X. 1911d: Letter to friends, December 1911. Mawson Collection, South Australian Museum. MI 16.

Mornement, H. 2004: In the steps of my ancestor. James Caird Society Journal 2: 23-35.

Moyser, A.E. 1919: Letter to Captain J.K. Davis, 6 March 1919. State Library of Victoria. MS 8311; 3231/4.

National Zeitung newspaper (Basel, Switzerland), 1910: 23 November 1910, p. 20.

Ninnis, B.E.S. 1911 (cited by B. Riffenburgh 2011). Diary entry 29 November 1911. Scott Polar Research Institute, Cambridge, England.

Petrow, S. 2002: Servicing the city: water, street lighting and trams in Hobart 1858-1914. In Living \& Working in Hobart: Historical Perspectives. Papers and Proceedings of the conference held by the Professional Historians Association (Tasmania) on 30 October 2002: pp. 39-57.

Riffenburgh, B. 2011: Aurora: Douglas Mawson and the Australasian Antarctic Expedition 1911-14. The Erskine Press, Norwich: 525 pp.

Ritz, H.B. 1909: The speech of the Tasmanian Aborigines. Papers and Proceedings of the Royal Society of Tasmania 1909: 44-81.

Ritz, H.B. 1913: Notes on native words of the Oyster Bay tribe. Papers and Proceedings of the Royal Society of Tasmania 1913: 82-94.

Ritz, H.B. 1913: Letter to the Prime Minister of Australia. 11 September. University of Sydney Archives. Edgeworth David Papers. Series 7, P.11.

Roberts, M. 1904-1921: Beaumaris Zoo Visitors' Book, Sandy Bay. 5 December 1911. Tasmanian Archives and Heritage Collection, LINC Tasmania. NS823/1/17.

Rossiter, H. (ed.) 2011. Mawson's Forgotten Men: the Antarctic Diaries of C.T. Harrisson 1911-1913. Pier 9, Sydney: 299 pp.

Shackleton, E. (with H.R. Mill \& T.W.E. David) 1909: The Heart of the Antarctic. Vols. 1 \& 2. William Heinemann, London.

Southcott, R.V., Chesterfield, N.J. \& Lugg, D.J. 1971: Vitamin A content of the livers of huskies and some seals from Antarctic and subantarctic regions. Medical Journal of Australia 6 February: 311-313

Tabart, T. 1911: Report, 9 November 1911. Mitchell Library, State Library of New South Wales, Sydney. Microfilm CY 3581, ML MSS 171/17.

Walch's Tasmanian Almanac for 1912. J. Walch \& Sons, Hobart: pp. $275-279$.

(accepted 17 April 2012) 